\title{
Bacterial resistance in bats from the Phyllostomidae family and its relationship with unique health ${ }^{1}$
}

\author{
Helio Sens-Junior², Wesley A. Trindade ${ }^{3}$, Aliny F. Oliveira ${ }^{2}$, Melissa M. Zaniolo², \\ Grazielli F. Serenini ${ }^{2}$, Jacqueline B. Araujo-Ceranto ${ }^{4}$, Daniela D. Gonçalves ${ }^{2}$ \\ and Ricardo M. Germano ${ }^{2 *}$
}

\begin{abstract}
Sens-Junior H., Trindade W.A., Oliveira A.F., Zaniolo M.M., Serenini G.F., Araujo-Ceranto J.B., Gonçalves D.D. \& Germano R.M. 2018. Bacterial resistance in bats from the Phyllostomidae family and its relationship with unique health. Pesquisa Veterinária Brasileira 38(6)1207-1216. Programa de Pós-Graduação em Ciência Animal com Ênfase em Produtos Bioativos, Universidade Paranaense, Praça Mascarenhas de Moraes 4282, Zona III, Umuarama, PR 87502-210, Brazil. E-mail: prof.ricardogermano@gmail.com

The Phyllostomidae family is important among the bats found in Brazil, with several species and diverse eating habits, and is the only one to have frugivorous representatives. These bats can be found in urban and in wild life environments in search for the best reproductive and feeding conditions. The versatility of environments can be associated with the incidence and/or distribution of some diseases through pathogenic agents. The present paper has the purpose to identify the oral and perianal microbiota and to detect the bacterial resistance of frugivorous bats captured near communities inhabited by humans in the northwestern region of the state of Paraná. A total of 68 bats were captured, belonging to four species of the Phyllostomidae family, namely Artibeus lituratus, Artibeus planirostris, Carollia perspicillata and Sturnira lillium, originated from forest fragments in the micro region of Umuarama, state of Paraná. A total of 64 isolates from oral bacteria and 39 from perianal region were submitted to identification. They were later submitted to a susceptibility test to 22 human and veterinary antimicrobials. The most prevalent bacteria were Escherichia coli $33.3 \%$ in the oral region, and $35.90 \%$ in the perianal region, Enterobacter aerogenes $12.7 \%$ and 5.13\%, Enterobacter agglomerans $7.9 \%$ and $10.25 \%$, and Serratia liquefaciens $9.5 \%$ and $5.13 \%$ in the oral and perianal region respectively. All bat species studied had resistant strains, with a few of them presenting multi-resistance to antimicrobials. The species with the highest multi-resistance index to antimicrobials was Carollia perspicillata, with three strains of the oral region resistant to 15 antimicrobials; it also presented two strains in the perianal region, which were resistant to 13 and 10 antimicrobials respectively. Based on the results found, it is possible to conclude that the oral and perianal microbiota of bats is composed of several enterobacterial species resistant to one or several antimicrobials used in human and veterinarian medicine. This is an issue and a future warning for unique health, since high percentages of resistance were found against antimicrobials broadly used, such as ampicillin, amoxicillin and amoxicillin+clavulonate.
\end{abstract}

INDEX TERMS: Bacterial resistance, bats, Phyllostomidae, frugivorous bats, gram-negative bacilli, wild animals, bacterioses.

\footnotetext{
${ }^{1}$ Received on December 22, 2017.

Accepted for publication on January 19, 2018.

${ }^{2}$ Programa de Pós-Gaduação em Ciência Animal com Ênfase em Produtos Bioativos, Universidade Paranaense (Unipar), Praça Mascarenhas de Moraes 4282, Zona III, Umuarama, PR 87502-210, Brazil. *Corresponding author: prof.ricardogermano@gmail.com

${ }^{3}$ Hospital Veterinário, Faculdade de Medicina Veterinária, Universidade Paranaense (Unipar), Rodovia PR-480 Km 14, Bonfim, Umuarama, PR 87502-970.

${ }^{4}$ Programa de Pós-Gaduação em Ciências Biológicas, Universidade Estadual de Londrina (UEL), Rodovia Celso Garcia Cid PR-455 Km 380, Londrina, PR 86057-970, Brazil.
}

RESUMO.- [Resistência bacteriana em morcegos da família Phyllostomidae e sua relação com a saúde única.] A família Phyllostomidae se destaca entre as famílias de morcegos encontrados no Brasil, com diversificadas espécies e hábitos alimentares, sendo a única a apresentar representantes frugívoros, podendo ser encontrada tanto em meio urbano, como de vida livre, em busca de melhores condições reprodutivas e alimentares. Essa versatilidade de ambientes pode estar associada à incidência e/ou distribuição de determinadas 
doenças por agentes patogênicos. 0 presente trabalho objetivou identificar a microbiota oral e perianal e detectar a resistência bacteriana em morcegos frugívoros capturados próximos às comunidades habitadas pelo homem na região noroeste do estado do Paraná. Foram capturados 68 morcegos, de quatro espécies da família Phyllostomidae, são eles Artibeus lituratus, Artibeus planirostris, Carollia perspicillata e Sturnira lillium, oriundos de fragmentos de Mata da microrregião de Umuarama, estado do Paraná. Um total de 64 isolados de bactérias da região oral e 39 da região perianal foram submetidos, identificação e posteriormente teste de susceptibilidade a 22 antimicrobianos de uso humano e veterinário. As bactérias mais prevalentes foram Escherichia coli 33,3\% na região da boca e 35,90\% na região perianal, Enterobacter aerogenes 12,7\% e 5,13\%, Enterobacter agglomerans 7,9\% e 10,25\% e Serratia liquefaciens $9,5 \%$ e $5,13 \%$ na região da boca e perianal, respectivamente. Todas as espécies de morcegos estudadas apresentaram cepas que foram resistentes, e algumas multirresistência aos antimicrobianos. A espécie que apresentou maior índice de multirresistência aos antimicrobianos foi Carollia perspicillata, com três cepas na região oral resistente a 15 antimicrobianos, e duas na perianal, com resistência a 13 e 10 antimicrobianos respectivamente. Baseados nos resultados encontrados, é possível concluir que a microbiota oral e perianal de morcegos, é composta por diversas espécies de enterobactérias, resistentes a um, ou vários antimicrobianos utilizados na medicina humana e veterinária, tornando-se um problema, e um alerta futuro para a saúde única, uma vez que foram encontrados elevados percentuais de resistência contra antimicrobianos utilizados em larga escala tais como ampicilina, amoxicilina e amoxicilina+clavulonato.

TERMOS DE INDEXAÇÃO: Resistência bacteriana, morcegos, Phyllostomidae, animais selvagens, bacilos Gram-negativos, filostomídeos, morcegos frugívoros, bacterioses.

\section{INTRODUCTION}

Bats are mammals belonging to the order Chiroptera, one of the most diversified groups in the class Mammalia regarding the number of species. Chiroptera is one of the orders presenting the most peculiar characteristics among mammals, being the only ones presenting structures that allow true flight, as well as an advanced echolocation.

The group is formed by 18 families, 202 genera and 1,120 species, representing $25 \%$ of the mammals registered and identified to world. In Brazil, there are nine families, represented by 65 genera and 175 species (Miretzki 2003, Jones et al. 2005, Simmons 2005, Reis et al. 2013).

The Brazilian bat families are present in the entire country, with the Phyllostomidae family being the only one with frugivorous representatives in the Neotropical region, with 56 genera grouped into 11 subfamilies, broadly distributed throughout all regions in the country, including urban areas (Baker et al. 2003, Peracchi et al. 2006).

Among all eating habits described for Chiroptera, the Phyllostomidae family has the most diversified one, with not only piscivorous habit described (Gregorin \& Taddei 2002, Reis et al. 2013).

The Stenodermatinae subfamily holds the largest group, with 67 species from the 191 ones described for the Phyllostomidae family. From the 17 genera known within that subfamily, 12 can be found in Brazil, accumulating to a total of 33 species. It can be morphologically characterized by the amplitude of the forearm, which ranges from $25 \mathrm{~mm}$ in Ametrida up to $75 \mathrm{~mm}$ in large Artibeus, with the Artibeus and the Sturnira genera being the most frequent ones in this subfamily (Miretzki 2003, Hortêncio-Filho et al. 2005). They usually present clear facial lists, which are evident in some species and weak or even absent in others. Another characteristic is a medial clear list over the body in some species, with nasal leaf, tail with short or even absent uropatagium (Simmons 2005, Zórtea 2007).

In the Carolliinae subfamily, two genera and nine species are found; in Brazil two genera are described with seven species (Simmons 2005, Hortêncio-Filho et al. 2007).

The bats in these subfamilies are predominantly frugivorous, and a few of them complete their diet with floral resources, small arthropods and even leaves. The preference for fruits and the increase of anthropic activities make them seek new sources of food or new foraging areas, forcing them to move in search of energetic resources. This plays an important role in the recovery of forests affected by human activity (Zórtea 2007). On the other hand, they can be associated with the incidence and/or distribution of certain variants caused by pathogenic agents, as well as transporting several ectoparasites that cause diseases. The pathogens that have bats as reservoir use their flight skills as a means of dispersal and acquisition of new niches (Friggens \& Beier 2010, Tompkins et al. 2011).

According to Passos et al. (2003), the fact that bats are found in urban and rural areas is related to the food availability, which influences the permanence of bats in a certain area and, consequently, when there is a lack of food, they can move to other regions (Gregorin \& Taddei 2002).

The oral microbiota in animals and humans consist in a large diversity of fungi and bacteria, as well as the gastrointestinal microbiota. The intestinal microbiota requires special attention due to its variety of microorganisms since it is a region subject to great exposure and there are several sources of bacteria originated from food, water, soil and other animals which have narrow symbiotic relationship in their natural environment (Wells et al. 2014, von Wintersdorff et al. 2014). In many animals, the oral microbiota is composed by species from the intestinal microbiota, depending on the hygiene, eating habits and social interaction of such species. However, external factors might change this microbiota (Martins et al. 2013).

The Enterobacteriaceae family is composed by a broad range of genera of both human and veterinarian clinical interest (Trabulsi \& Alterthum 2004). This microbiota is defined as gram-negative bacilli, which are characterized by laboratory growth in MacConkey agar, since they are tolerant to the inhibition of biliary salts present in the formulation of this medium (Quinn et al. 2007).

Resistance to antimicrobials is a threat to unique health in the whole world, since it limits the options of clinical treatment against bacterial infections (von Wintersdorff et al. 2014). The indiscriminate use of antimicrobials in animals has become a concern of many scholars (van Den Bogaard \& Stobberingh 2000, Normanno et al. 2007) due to the increase in the frequency of reports of bacterial resistance to these medications, both in humans and in other animals.

In the environment, risks are also imminent. Wild animals that are not directly in contact with these microorganisms have been contaminated by air or by earth, resulting in the 
dissemination of resistance to these bacteria that are usually found in urban areas (Mateu \& Martin 2001).

Antimicrobials are usually used in pets aiming at their protection and well-being, as prophylaxis of diseases and also as a performance improver, as well as several other justifications for the use of these drugs, which become vital and difficult to be substituted if there is no viable alternative (Ungemach et al. 2006, Mion et al. 2014).

Bats, with their flight capacity, present easy displacement and can migrate from one region to another, allowing them to be more easily exposed to antimicrobials, increasing the risk of developing, changing or acquiring a new microbiota. The bacteria transmitted by bats are a public health issue that is even more difficult to be eradicated and/or controlled (Perkins et al. 2005, Omatsu et al. 2007).

With the reduction of the natural habitats of wild animals caused by the increase of anthropic activities, there was an approximation of these animals to the human beings, enabling an easier transmission of bacteria of zoonotic interest, and consequent increase in the virulence power of these microorganisms (Santos et al. 2010).

The study of wildlife inhabiting regions near communities of humans has been object of great interest. Therefore, the purpose of this study was to identify the oral and perianal microbiota and detect the bacterial resistance in frugivorous bats captured in the micro region of Umuarama, in northwestern Paraná state.

\section{MATERIALS AND METHODS}

Description of study areas. The study area is located in the northwestern region of the state of Paraná, at $613 \mathrm{~km}$ from Curitiba, the physiographic region known as Ivaí, latitude $23^{\circ} 47^{\prime} 55^{\prime \prime} \mathrm{S}$ and longitude $53^{\circ} 18^{\prime} 48^{\prime \prime} \mathrm{W}$. They are situated at the tropical pluvial zone, presenting mesothermal humid subtropical, rainy weather, warm temperate, with rare night frosts. The average temperatures in the warmest months (September-March) is higher than $22^{\circ} \mathrm{C}$, and on the coldest months (April-August) it is lower than $18^{\circ} \mathrm{C}$, with hot summers, very few frosts and a tendency of rain concentrated in the summer months, but with no dry season defined (Iapar 2015).

The study was performed in three fragments of Atlantic Forest of the geographic micro region of Umuarama (Ipardes 2012). It was approved by the Ethics Committee in Research Involving Animal Experimentation (CEPEEA) at Universidade Paranaense, protocol $27844 / 2015$ and authorized by Instituto Chico Mendes de Conservação da Biodiversidade, ICMBio (SISBio 33.732-1).

They were named as fragment I, II and III according to their areas, from the smallest to the largest, each one being near the double of each other:

Fragment I: located at $7.3 \mathrm{~km}$ northeast of the city of Umuarama, with an area of 36.7 ha, between the coordinates $23^{\circ} 42^{\prime} 15^{\prime \prime} \mathrm{S}$ and $53^{\circ} 14^{\prime} 43^{\prime \prime} \mathrm{W}$.

Fragment I: located at $7.5 \mathrm{~km}$ northeast of the city of Umuarama, with an area of 65.1 ha, between the coordinates $23^{\circ} 42^{\prime} 24^{\prime \prime} \mathrm{S}$ and $53^{\circ} 13^{\prime} 17^{\prime \prime}$.

Fragment III: $13.9-\mathrm{km}$ far from the city, also in the northeast region, with an area of 230 ha, between the coordinates $23^{\circ} 41^{\prime} 56^{\prime \prime} \mathrm{S}$ and $53^{\circ} 23^{\prime} 55^{\prime \prime} \mathrm{W}$.

The surroundings of fragments I and II are basically grazing areas, and fragment III has citrus crops, mainly orange.

Capture of animals. The capture of bats had an average duration of 12 hours, starting right after sunset and finishing at dawn. Two mist nets measuring nine meters long and three meters wide were used, assembled in trails inside the forest, checked every 15 minutes. The sampling points were established according to the most appropriate locations to assemble the nets, which are the same locations that present the activity of animal foraging.

After the capture, the animals were stored in cotton bags in order to reduce their stress, and after their escape movements were reduced, all animals were identified with the aid of identification keys Vizotto \& Taddei (1973), Greenhall et al. (1983), Gregorin \& Taddei (2002), Lim et al. (2004), Simmons (2005), Barquez \& Diaz (2009) and Reis et al. (2013).

Right after the capture, an identification form was filled out for each animal, containing data related to the location and time of capture, which helped in the use of the identification key. After identification and the collection of samples, the animals were released at the same location that they had been captured.

Collection of biological samples. The materials were forwarded under refrigeration in isothermal container to the Laboratory of Preventive Veterinary Medicine and Public Health at the Master Degree in Animal Science at Universidade Paranaense (UNIPAR) for later processing of laboratory techniques and analysis of data.

Sterile GS-03-Metal Rod swabs were used for the perianal and oral region. Circular and pressure movements were performed on the perianal region; for the oral region, the swab was inserted in the animal mouth and circular and rotating movements were made on the gums and tongue. Both swabs were inserted in test tubes with threaded lids containing Brain Heart Infusion (BHI) medium for later processing.

Laboratory techniques. A total of 64 isolates from oral bacteria and 39 from perianal region were submitted to identification. They were later submitted to a susceptibility test to 22 human and veterinary antimicrobials.

The samples were kept in microbiological oven for 48 hours at $37^{\circ} \mathrm{C}$. For conservation purposes, all samples were replicated in BHI medium with glycerol $80 \%$ and then stored at $-20^{\circ} \mathrm{C}$.

The cultures obtained were replicated by striation in plates containing MacConkey agar and kept in microbiological oven at $37^{\circ} \mathrm{C}$ for 24 hours for the isolation of pure colonies.

The biochemical identification of bacteria belonging to the Enterobacteriaceae family was performed by using the enterobacterial commercial kit from Newprov $^{\circledR}$, following the manufacturer's recommendations. The identification of the bacterial species was performed according to Quinn et al. (2007), evaluated the following parameters: dehydration of L-Tryptophan or Tryptophan deaminase, production of hydrogen sulphide gas $\left(\mathrm{H}_{2} \mathrm{~S}\right)$, glucose fermentation, production of gas from glucose, decarboxylation of L-Lysine, production of Indol, decarboxylation of Ornithine, motility, citrate use as the sole source of carbon and fermentation of Rhamnose. The bacterial identified were submitted to the antimicrobial susceptibility test using the disk-agar diffusion method following the parameters from the Clinical and Laboratory Standards Institute - CLSI (2013) for the following antimicrobials: ertapenem (ERT-10 $\mu \mathrm{g}$ ); nalidixic acid (NAL-30 $\mu \mathrm{g}$ ); ciprofloxacin (CIP-5 $\mu \mathrm{g})$; sulfazotrim (SUT-25 $\mu \mathrm{g}$ );

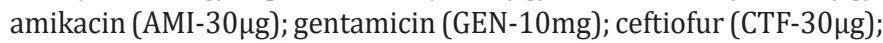
meropenem (MPM-10mg); imipenem (IPM-10mg); tetracycline (TET-30 $\mu$ ); ampicillin (AMP-10mg); amoxicillin (AMO-10mg); cefepime (COM-30 $\mu$ ); tobramycin (TOB-10mg); ceftazidime

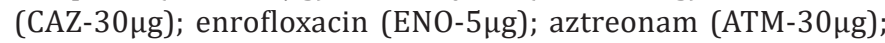
amoxicillin + clavulanic acid (AMC-30 $\mu \mathrm{g})$; ceftriaxone (CRO-30 $\mu \mathrm{g}$ ); chloramphenicol (CLO-30 $\mu \mathrm{g})$; cefotaxime (CTX-30 $\mu \mathrm{g})$; cefotaxitine

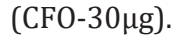




\section{RESULTS AND DISCUSSION}

During the collection period, a total of 68 bats were captured, all belonging to the Phyllostomidae family, divided into four species Carollia perspicillata (C. perspicillata $=37-54.4 \%$ ), Sturnira lillium (S. lillium $=9-13.2 \%)$, Artibeus lituratus (A. lituratus $=14-20.6 \%)$ and Artibeus planirostris (A. planirostris $=8-11.8 \%)($ Table 1$)$. The phyllostomid are endemic of the Neotropical region, and are predominant in the bat communities (Koopman 1993). Bianconi et al. (2004) studying the diversity of bats in the northwestern region of Paraná, emphasizes the predominance of this family of bats, both in number and in the wealth of species, mainly by their eating versatility, since many times these animals need to leave the remaining forest regions to seek food in orchards cultivated for commercial purposes or for family consumption (Passos et al. 2003). The absence of capturing other bat families is possibly due to the selectivity of the position of the mist net, since this method favors the capturing of bats that use the sub-forest to move around (Bianconi et al. 2004, Straube \& Bianconi 2014).

Bats of the genus Artibeus were captured in the three collection areas, predominantly in area I (Table 1). This area is the smallest of the areas studies, favoring the permanence of this genus, which has the characteristic of low fidelity to the permanence area, presenting the habit of moving over long distances, mainly for foraging (Costa et al. 2006, Esbérard et al.
2011). It is also important to emphasize that this area is the nearest to the city, favoring the search for food in urban areas as a complement to their diets.

The species $C$. perspicillata was captured in the greatest number in area II (Table 1), the same happening with S. lillium. There two genera are the most faithful to the foraging area (Costa et al. 2006), mainly when there is dominance of pioneering species, such as piperaceas, which are common in subtropical forests (Reis et al. 2006).

Regarding the bacterial isolation, a total of 55 isolates were detected in the oral region and 32 isolates in the perianal region in the four species studied (Table 2 and 3 ). There was no bacterial growth in $25(36.77 \%)$ samples from the oral region and $39(57.35 \%)$ from the perianal region with the methodology employed for gram-negative bacilli.

The absence of bacterial growth is also described by Nascimento et al. (2003) in their work on birds from the Atlantic rainforest in Brazil, reporting that unfavorable results might occur due to death and consequent decrease of bacteria during the storage in field or even during transportation. However, there was no commitment of the data in this paper.

Regarding the bacterial population described and the resistance of these bacteria to the antimicrobials tested, the results presented are related to a small number of frugivorous bats. However, they are of great relevance, since data related to the microbiota of these animals are still nonexistent in

Table 1. Frugivorous bats species captured in the three study areas in the micro-region of Umuarama, Northeast Paraná, 2015

\begin{tabular}{ccccc}
\hline \multirow{2}{*}{ Collection points } & \multicolumn{4}{c}{ Number of individuals per area } \\
\cline { 2 - 5 } & Artibeus lituratus & Artibeus planirostris & Carollia perspicillata & Sturnira lillium \\
\hline I & 12 & 8 & 1 & 30 \\
II & 1 & - & 6 & 5 \\
III & 1 & - & 37 & 3
\end{tabular}

Table 2. Bacteria isolated from swab samples in the oral region of frugivorous bats from the Phyllostomidae family originated from forest fragments in the micro-region of Umuarama, Northeast Paraná, 2015

\begin{tabular}{|c|c|c|c|c|c|}
\hline \multirow[b]{2}{*}{ Isolated strains } & \multicolumn{5}{|c|}{ Species of bats, samples of the oral region } \\
\hline & $\begin{array}{l}\text { Artibeus lituratus } \\
\qquad \begin{array}{c}\mathrm{n}=14 \\
\mathrm{c}=13\end{array}\end{array}$ & $\begin{array}{l}\text { Artibeus planirostris } \\
\qquad \begin{array}{c}n=8 \\
c=8\end{array}\end{array}$ & $\begin{array}{l}\text { Carollia perspicillata } \\
\qquad \begin{array}{l}\mathrm{n}=37 \\
\mathrm{c}=17\end{array}\end{array}$ & $\begin{array}{c}\text { Sturnira } \\
\text { Iillium } \\
\begin{array}{c}\mathrm{n}=9 \\
\mathrm{c}=5\end{array}\end{array}$ & (\%) Total \\
\hline Enterobacter aerogenes & $6(25.00 \%)$ & 0 & $1(6.67 \%)$ & $1(16.67 \%)$ & $8(14.60 \%)$ \\
\hline Enterobacter agglomerans & 0 & 0 & $4(26.67 \%)$ & $1(16.67 \%)$ & $5(9.09 \%)$ \\
\hline Enterobacter cloacae & 0 & $2(20.00 \%)$ & $1(6.67 \%)$ & 0 & $3(5.45 \%)$ \\
\hline Erwinia herbicola & $1(4.17 \%)$ & 0 & $2(13.33 \%)$ & 0 & $3(5.45 \%)$ \\
\hline Escherichia coli & $11(45.83 \%)$ & $5(50.00 \%)$ & $2(13.33 \%)$ & $3(50.00 \%)$ & $21(38.19 \%)$ \\
\hline Kluyvera spp. & 0 & $1(10.00 \%)$ & 0 & 0 & $1(1.81 \%)$ \\
\hline Koserella trabulsii & $2(8.33 \%)$ & 0 & 0 & 0 & $2(3.63 \%)$ \\
\hline Morganella morganii & 0 & $1(10.00 \%)$ & 0 & 0 & $1(1.81 \%)$ \\
\hline Proteus mirabilis & $1(4.17 \%)$ & 0 & $2(13.33 \%)$ & 0 & $3(5.45 \%)$ \\
\hline Serratia liquefaciens & $2(8.33 \%)$ & $1(10.00 \%)$ & $2(13.33 \%)$ & $1(16.67 \%)$ & $6(10.90 \%)$ \\
\hline Serratia rubidae & $1(4.17 \%)$ & 0 & 0 & 0 & $1(1.81 \%)$ \\
\hline Shigella spp. & 0 & 0 & $1(6.67 \%)$ & 0 & $1(1.81 \%)$ \\
\hline Total strains & $24(100 \%)$ & $10(100 \%)$ & $15(100 \%)$ & $6(100 \%)$ & $55(100 \%)$ \\
\hline
\end{tabular}

$\mathrm{n}=$ number of individuals, $\mathrm{c}=$ number of samples showing growth for gram-negative bacteria. 
Table 3. Bacteria isolated from swab samples in the perianal region of frugivorous bats from the Phyllostomidae family originated from forest fragments in the micro-region of Umuarama, Northeast Paraná, 2015

\begin{tabular}{|c|c|c|c|c|c|}
\hline \multirow[b]{2}{*}{ Isolated strains } & \multicolumn{5}{|c|}{ Species of bats, samples of the perianal region } \\
\hline & $\begin{array}{c}\text { Artibeus lituratus } \\
\qquad \begin{array}{c}\mathrm{n}=14 \\
\mathrm{c}=10\end{array}\end{array}$ & $\begin{array}{l}\text { Artibeus planirostris } \\
\qquad \begin{array}{c}\mathrm{n}=8 \\
\mathrm{c}=7\end{array}\end{array}$ & $\begin{array}{l}\text { Carollia perspicillata } \\
\qquad \begin{array}{c}\mathrm{n}=37 \\
\mathrm{c}=6\end{array}\end{array}$ & $\begin{array}{c}\text { Sturnira } \\
\text { lillium } \\
\mathrm{n}=9 \\
\mathrm{c}=6\end{array}$ & (\%) Total \\
\hline Enterobacter aerogenes & $1(6.67 \%)$ & $1(14.29 \%)$ & 0 & 0 & $2(6.26 \%)$ \\
\hline Enterobacter agglomerans & $1(6.67 \%)$ & $1(14.29 \%)$ & $1(25.00 \%)$ & $1(16.67 \%)$ & $4(12.50 \%)$ \\
\hline Erwinia herbicola & 0 & $3(42.85 \%)$ & $2(50.00 \%)$ & 0 & $5(15.62 \%)$ \\
\hline Escherichia coli & $7(46.66 \%)$ & $2(28.57 \%)$ & $1(25.00 \%)$ & $4(66.66 \%)$ & $14(43.75 \%)$ \\
\hline Ewingella americana & 0 & 0 & 0 & $1(16.67 \%)$ & $1(3.12 \%)$ \\
\hline Kluyvera spp. & $1(6.67 \%)$ & 0 & 0 & 0 & $1(3.12 \%)$ \\
\hline Koserella trabulsii & $3(20.00 \%)$ & 0 & 0 & 0 & $3(9.37 \%)$ \\
\hline Serratia liquefaciens & $2(13.33 \%)$ & 0 & 0 & 0 & $2(6.26 \%)$ \\
\hline Total strains & $15(100 \%)$ & $7(100 \%)$ & $4(100 \%)$ & $6(100 \%)$ & $32(100 \%)$ \\
\hline
\end{tabular}

$\mathrm{n}=$ number of individuals, $\mathrm{c}=$ number of samples showing growth for gram-negative bacteria.

scientific literature, nor there are data related to antimicrobial resistance.

From the Enterobacteriaceae family, Escherichia coli (E. coli) was isolated in $21(33.3 \%)$ samples from the oral cavity and $14(35.9 \%)$ from the perianal one (Table 2 and 3$)$. This incidence in relation to other enterobacteria has already been reported by other researchers for wild and domestic animals (Santos et al. 2010, Corrêa et al. 2013), being mentioned as the bacterial class of highest prevalence in the world (Gerlach 1994).

E. coli is a bacterium with high zoonotic potential, with great relevance for unique health, which can be expressed as a measure of environmental contamination, as well as anthropic action. In other words, it is related to the contamination of natural environments, being present in the gastrointestinal tract of humans and different species of animals (Carvalho 2007).

Bats are the only mammals presenting the ability to fly. Therefore, they can migrate from one location to another, easing the acquisition or change of their natural microbiota, in order to adhere to resistance mechanisms to certain known antimicrobials used in both human and animal medicine.

Bacteria from the Enterobacter aerogenes species were isolated in eight $(12.7 \%)$ samples from the oral and two $(5.13 \%)$ from the perianal cavity, being the second group with the highest percentage of isolation. It is a pathogen considered opportunistic, which is usually from hospitals, possibly originated from hospitalization, invasive surgeries, visits in the intensive care unit and high use of antimicrobials, causing difficulty in the institution of treatment to the patient (Paterson 2006).

The bacteria isolated in the oral region of $A$. lituratus totaled 24 isolates (Table 2). Among them, E. coli $(11 / 24=45.43 \%)$ presented resistance to the antimicrobials AMP and AMO $(4 / 11=36.36 \%)$, TET $(3 / 11=27.27 \%)$. Enterobacter aerogenes (E. aerogenes $6 / 24=25 \%$ ) (Table 2) was resistant to AMO, AMP and AMC $(5 / 6=83.33 \%)$ and to CFO $(4 / 6=66.66 \%)$. The other enterobacteria found in the oral region presented resistance to at least two of the three antimicrobials tested in the penicillin class (Table 4).

Six enterobacteria species were isolated from the perianal region of A. lituratus. A total of 15 strains presented growth
(Table 3), being seven E. coli $(7 / 15=46.66 \%)$ presenting resistance to AMO, AMP (71.43\%); in 100\% of the Koserella trabulsii (K. trabulssi) strains, there was resistance to AMP and AMC; the remaining strains presented resistance to at least two of the three antimicrobials in the penicillin class (Table 4).

Samples from eight $A$. planirostris specimens were analyzed, and presented growth of 10 isolates for enterobacteria in the oral (Table 2) and seven in the perianal region (Table 3). Similar to the A. lituratus species, the E. coli isolates were resistant to AMP and AMO in the oral cavity $(1 / 5=20 \%)$; and in the perianal region, $100 \%$ of the isolates were resistant to AMP and AMO (Table 5).

The isolates from the oral region of A. planirostris: Enterobacter cloacae (E. cloacae), Serratia liquefaciens (S. liquefaciens) and Morganella morganii (M. morganii) were resistant to the three antimicrobials tested from the penicillin class (Table 5).

The high number of $E$. coli isolates was expected, since the bacterium is frequently found in other wild animals already studied, such as in $70.5 \%$ of cloaca samples of captive cracids (Santos et al. 2010) in 20\% of the cloaca samples of psittacids from a conservationist breeder (Mattes et al. 2005), and from 90 " of the fecal samples from marine birds by Steele et al. (2005).

Regarding the resistance detected in penicillins, this may have a narrow relation with the coexistence of bats with pets and commercial animals, since the areas surrounding collection area I, where individuals of the A. lituratus species were captured, is formed by grazing areas and consortium farming (agriculture and cattle breeding). Therefore, the relationship between these bats and the animals kept in that area allows the suggestion of bacteria exchange, thus allowing wild animals to acquire bacteria with resistance genes, possibly due to the sharing of water with different species of animals presented in the area.

A. planirostris were captured exclusively in area I. This species presents characteristics that are peculiar to its genus, that is, its migration in search for food (Reis et al. 2006), which brings them closer to areas where the exposure to bacteria resistant to antimicrobials is possible, or even to those that can change their microbiota by expressing resistant strains, such as those described in the results herein. 
Table 4. Bacteria isolated from swab samples in the oral and perianal regions of frugivorous bats from the Artibeus lituratus species and resulting from bacterial transference against 22 antimicrobials by the disc-diffusion method

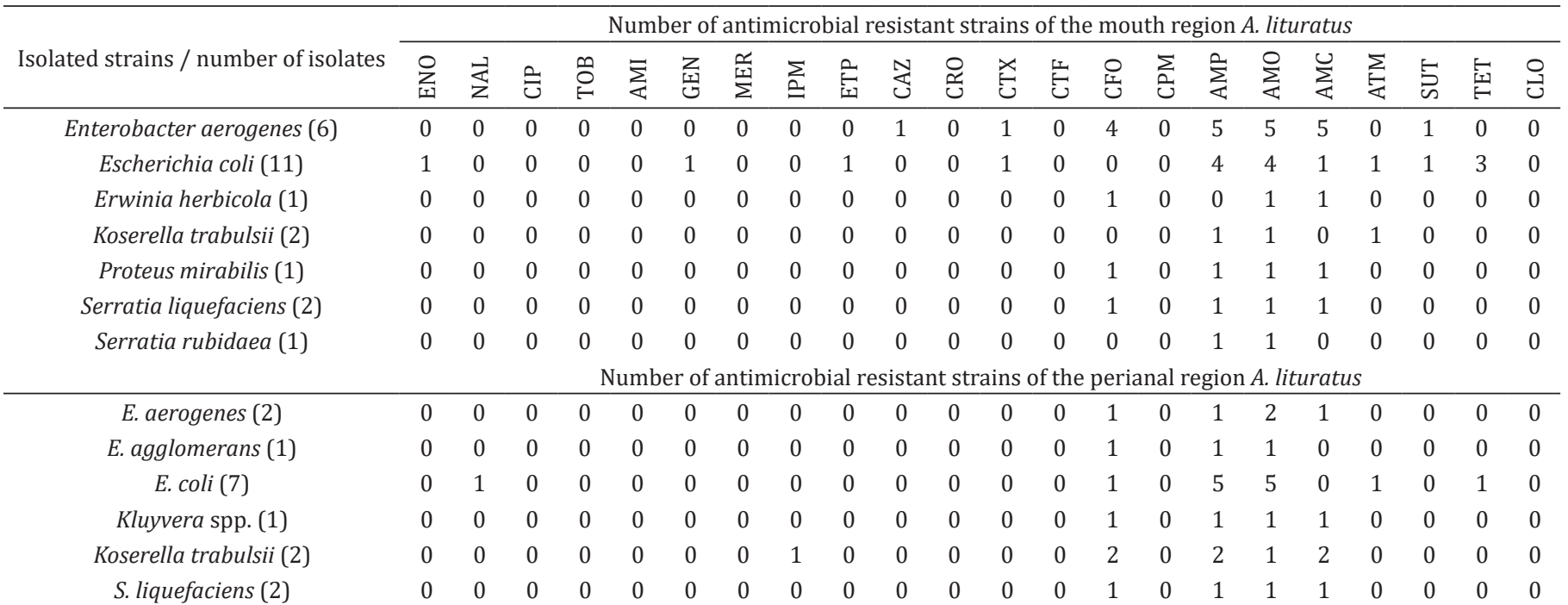

ENO = Enrofloxacin, NAL = nalidixic acid, $\mathrm{CIP}=$ ciprofloxacin, $\mathrm{TOB}=$ tobramycin, $\mathrm{AMI}=$ amikacin, GEN = gentamicina, $\mathrm{MPM}=$ meropenem, $\mathrm{IPM}=\mathrm{imipenem}$, $\mathrm{ERT}=$ ertapenem, $\mathrm{CAZ}=$ ceftazidime, $\mathrm{CRO}=$ ceftriaxone, $\mathrm{CTX}=$ cefotaxime, $\mathrm{CTF}=$ ceftiofur, $\mathrm{CFO}=$ cefotaxitine, $\mathrm{COM}=$ cefepime $\mathrm{AMP}=$ ampicillin, $\mathrm{AMO}=$ amoxicillin, $\mathrm{AMC}=$ amoxicillin + clavulanic acid, $\mathrm{ATM}=$ aztreonam, $\mathrm{SUT}=$ sulfazotrim, $\mathrm{TET}=$ tetracycline, $\mathrm{CLO}=$ chloramphenicol .

Table 5. Bacteria isolated from swab samples in the oral and perianal regions of frugivorous bats from the Artibeus planirostris species and resulting from bacterial transference against 22 antimicrobials by the disc-diffusion method

\begin{tabular}{|c|c|c|c|c|c|c|c|c|c|c|c|c|c|c|c|c|c|c|c|c|c|c|}
\hline \multirow[b]{2}{*}{ Isolated strains/number of isolates } & \multicolumn{22}{|c|}{ Number of antimicrobial resistant strains of the mouth region A. planirostris } \\
\hline & $\sum_{\text {II }}^{0}$ & $\underset{\Sigma}{\mathbb{Z}}$ & $\vartheta$ & $\stackrel{\oplus}{\circ}$ & $\sum$ & 忌 & 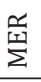 & $\sum_{\Xi}$ & 氠 & $\underset{\mathrm{J}}{\mathrm{J}}$ & 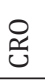 & 㫐 & 号 & $\begin{array}{l}\text { 온 } \\
\text { 足 }\end{array}$ & $\sum_{0}$ & $\sum_{i}^{0}$ & $\sum_{i}^{\circ}$ & $\sum_{i}^{U}$ & 定 & 它 & 包 & $\stackrel{\circ}{\hookrightarrow}$ \\
\hline E. cloacae (2) & 0 & 0 & 0 & 0 & 0 & 0 & 0 & 0 & 0 & 0 & 0 & 0 & 0 & 2 & 0 & 1 & 1 & 1 & 0 & 0 & 0 & 0 \\
\hline Escherichia coli (5) & 0 & 1 & 0 & 0 & 0 & 0 & 0 & 0 & 0 & 0 & 0 & 0 & 0 & 0 & 0 & 1 & 1 & 0 & 0 & 0 & 1 & 0 \\
\hline Kluyvera spp. (1) & 0 & 0 & 0 & 0 & 0 & 0 & 0 & 0 & 0 & 0 & 0 & 0 & 0 & 0 & 0 & 1 & 1 & 0 & 0 & 0 & 0 & 0 \\
\hline Morganella morganii (1) & 0 & 0 & 0 & 0 & 0 & 0 & 0 & 0 & 0 & 0 & 0 & 0 & 0 & 0 & 0 & 1 & 1 & 1 & 0 & 0 & 0 & 0 \\
\hline \multirow[t]{2}{*}{ Serratia liquefaciens (1) } & 0 & 0 & 0 & 0 & 0 & 0 & 0 & 0 & 0 & 0 & 0 & 0 & 0 & 1 & 0 & 1 & 1 & 1 & 0 & 0 & 0 & 0 \\
\hline & \multicolumn{22}{|c|}{ Number of antimicrobial resistant strains of the perianal region $A$. planirostris } \\
\hline Enterobacter aerogenes (1) & 0 & 0 & 0 & 0 & 0 & 0 & 0 & 0 & 0 & 0 & 0 & 0 & 0 & 1 & 0 & 1 & 1 & 0 & 0 & 0 & 0 & 0 \\
\hline Enterobacter agglomerans (1) & 0 & 1 & 0 & 0 & 0 & 0 & 0 & 0 & 0 & 0 & 0 & 0 & 0 & 0 & 0 & 0 & 0 & 0 & 0 & 0 & 0 & 0 \\
\hline E. coli $(2)$ & 1 & 0 & 0 & 0 & 0 & 0 & 0 & 0 & 0 & 0 & 0 & 0 & 0 & 0 & 0 & 2 & 2 & 0 & 1 & 0 & 0 & 0 \\
\hline Erwinia herbicola (3) & 0 & 1 & 0 & 0 & 0 & 0 & 0 & 0 & 0 & 0 & 0 & 0 & 0 & 1 & 0 & 1 & 2 & 0 & 0 & 0 & 1 & 0 \\
\hline
\end{tabular}

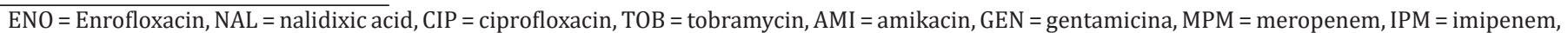

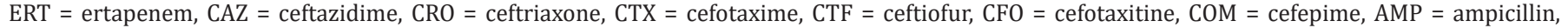
AMO = amoxicillin, AMC = amoxicillin + clavulanic acid, ATM = aztreonam, SUT = sulfazotrim, TET = tetracycline, CLO = chloramphenicol.

However, for Nascimento et al. (2003), the resistant to antimicrobials in natural environments could be related to pressures and change in the non-human environment, such as the natural production of antimicrobials by microorganisms, or even by the spontaneous mutation of genes (intrinsic), thus contributing to the maintenance and dissemination of these genes, which explains the high level of resistance in natural environments.

The same authors also believe that epidemiological studies on bacterial resistance in wild animals must be broadened, reassessing the assumption that the resistance starts in human and veterinarian hospitals, or in production animals, where these antimicrobials are used as performance improvers.
From the nine individuals of the $S$. lillium species captured, there was the growth of six isolates in the oral and six in the perianal region (Table 2 and 3). In all isolates in the oral region, resistance was found in at least two antimicrobials in the penicillin class; and for CFO in E. coli, the resistance was $33.33 \%$, in E. aerogenes and S. liquefaciens in $100 \%$ of the isolates.

Resistance was also found in the perianal region for CFO in E. coli in $25 \%$ of the isolates, in Enterobacter agglomerans (E. agglomerans), Enterobacter americana (E. americana) it was in $100 \%$ of the isolates. Regarding AMP and AMO in the perianal region, resistance was found in $75 \%$ of the E. coli samples, $100 \%$ of the E. agglomerans isolates (Table 6). 
Only six specimens in the $C$. perspicillata specimens presented growth in the perianal region. It is important to emphasize that the number of isolates for the gram-negative bacteria in this species was proportionally lower than for the other species $10.82 \%(4 / 37)$ (Table 3$)$ and in the oral region, in $45.95 \%$ (17/37), regarding the number of isolates for this region, they were 15 (Table 2).

Antimicrobials presenting greater resistance index were those in the penicillin class (AMO, AMP, AMC), similar to the other chiroptera species. Like the $S$. lillium species, there was a great resistance from different bacterial species to the CFO antibiotic (Table 7).

Still for the $C$. perspicillata species, an alarming result was found in three strains in the oral region, presenting multi resistance to 15 antimicrobials, and two strains in the perianal region, one with multi resistance to 13 and the other to 10 antimicrobials, among the 22 tested items (Table 7).
As previously mentioned, the Sturnira and Carollia genera are more faithful to the foraging area (Costa et al. 2006), with these two genera mainly captured in the study area II (Table 1) and this area was remarkable because in one of its margins, an uninhabited house was found, which was being used as a feed deposit for beef cattle raised on the property.

No bottles of antimicrobials in the location that may justify the exposure of those bats to these drugs were seen. However, since it is a large cattle breeding area, and the fact that these drugs are present in the Veterinary Medicine practice, it is possible that such house is used as a storage location, albeit temporarily, for these antimicrobials used in the treatment and cure of animals in the different breeding stages.

The $C$. perspicillata species is related to the environment as a biological preservation indicator, and its occurrence must be associated to pioneer fruit species for its preferential feeding. This vegetable maintenance depends on the interaction of

Table 6. Bacteria isolated from swab samples in the oral and perianal regions of frugivorous bats from the Sturnira lillium species and resulting from bacterial transference against 22 antimicrobials by the disc-diffusion method

\begin{tabular}{|c|c|c|c|c|c|c|c|c|c|c|c|c|c|c|c|c|c|c|c|c|c|c|}
\hline \multirow[b]{2}{*}{ Isolated strains/number of isolates } & \multicolumn{22}{|c|}{ Number of antimicrobial resistant strains of the mouth region S. lillium } \\
\hline & $\sum_{\text {뇌 }}^{\circ}$ & $\underset{z}{Z}$ & 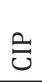 & $\stackrel{\wp}{\circ}$ & $\sum_{i}$ & 忌 & 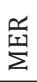 & $\sum_{\varrho}$ & 点 & $\underset{ن}{\mathcal{S}}$ & 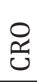 & 㫐 & 屶 & 오 & $\sum_{0}$ & $\sum_{<}^{Q}$ & $\sum_{<}^{0}$ & $\sum_{i}^{U}$ & $\sum_{\text {安 }}$ & $\stackrel{\hookleftarrow}{\hookleftarrow}$ & 島 & $\stackrel{\circ}{త}$ \\
\hline Enterobacter aerogenes (1) & 0 & 0 & 0 & 0 & 0 & 0 & 0 & 0 & 0 & 0 & 0 & 1 & 0 & 1 & 0 & 1 & 1 & 0 & 0 & 0 & 0 & 0 \\
\hline Enterobacter agglomerans (1) & 0 & 0 & 0 & 0 & 0 & 0 & 0 & 0 & 0 & 0 & 0 & 0 & 0 & 0 & 0 & 1 & 1 & 0 & 0 & 0 & 0 & 0 \\
\hline Escherichia coli (3) & 0 & 0 & 0 & 0 & 0 & 0 & 0 & 0 & 0 & 0 & 0 & 0 & 0 & 1 & 0 & 2 & 2 & 1 & 0 & 0 & 0 & 0 \\
\hline \multirow[t]{2}{*}{ Serratia liquefaciens (1) } & 0 & 0 & 0 & 0 & 0 & 0 & 0 & 0 & 0 & 0 & 0 & 0 & 0 & 1 & 0 & 1 & 1 & 0 & 0 & 0 & 0 & 0 \\
\hline & \multicolumn{22}{|c|}{ Number of antimicrobial resistant strains of the perianal region S. lillium } \\
\hline Ewingella americana (1) & 0 & 0 & 0 & 0 & 0 & 0 & 0 & 0 & 0 & 0 & 1 & 0 & 0 & 1 & 0 & 0 & 1 & 0 & 0 & 0 & 0 & 0 \\
\hline E. agglomerans (1) & 0 & 0 & 0 & 0 & 0 & 0 & 0 & 0 & 0 & 0 & 0 & 0 & 0 & 1 & 0 & 1 & 1 & 1 & 0 & 0 & 0 & 0 \\
\hline E. coli $(4)$ & 0 & 0 & 0 & 0 & 0 & 0 & 0 & 0 & 0 & 0 & 0 & 1 & 0 & 1 & 0 & 3 & 3 & 1 & 0 & 0 & 0 & 0 \\
\hline
\end{tabular}

ENO = Enrofloxacin, NAL = nalidixic acid, $\mathrm{CIP}=$ ciprofloxacin, $\mathrm{TOB}=$ tobramycin, $\mathrm{AMI}=$ amikacin, $\mathrm{GEN}=$ gentamicina, $\mathrm{MPM}=$ meropenem, $\mathrm{IPM}=\mathrm{imipenem}$, $\mathrm{ERT}=$ ertapenem, $\mathrm{CAZ}=$ ceftazidime, $\mathrm{CRO}=$ ceftriaxone, $\mathrm{CTX}=$ cefotaxime, $\mathrm{CTF}=$ ceftiofur, $\mathrm{CFO}=$ cefotaxitine, $\mathrm{COM}=$ cefepime, $\mathrm{AMP}=\mathrm{ampicillin}$, $\mathrm{AMO}=$ amoxicillin, $\mathrm{AMC}=$ amoxicillin + clavulanic acid, $\mathrm{ATM}=$ aztreonam, $\mathrm{SUT}=$ sulfazotrim, $\mathrm{TET}=$ tetracycline, $\mathrm{CLO}=$ chloramphenicol.

Table 7. Bacteria isolated from swab samples in the oral and perianal regions of frugivorous bats from the Carollia perspicillata species and resulting from bacterial transference against 22 antimicrobials by the disc-diffusion method

\begin{tabular}{|c|c|c|c|c|c|c|c|c|c|c|c|c|c|c|c|c|c|c|c|c|c|c|}
\hline \multirow[b]{2}{*}{ Isolated strains/number of isolates } & \multicolumn{22}{|c|}{ Number of antimicrobial resistant strains of the mouth region C. perspicillata } \\
\hline & $\sum_{\text {뇌 }}^{\circ}$ & 克 & 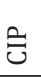 & $\stackrel{\oplus}{\circ}$ & $\sum_{4}$ & 乙 & $\frac{\text { 舀 }}{\sum}$ & $\sum_{\equiv}$ & 泀 & $\underset{ن}{\mathcal{S}}$ & 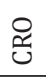 & 㫐 & 号 & ○્ટ & $\sum_{0}$ & $\sum_{<}^{0}$ & $\sum_{<}^{0}$ & $\sum_{\ll}^{\cup}$ & 意 & 占 & 勻 & త \\
\hline Enterobacter aerogenes (1) & 0 & 0 & 0 & 0 & 0 & 0 & 0 & 0 & 0 & 0 & 0 & 0 & 0 & 1 & 0 & 1 & 1 & 1 & 0 & 0 & 0 & 0 \\
\hline Enterobacter agglomerans (4) & 0 & 0 & 0 & 0 & 0 & 0 & 1 & 1 & 1 & 2 & 1 & 1 & 1 & 1 & 1 & 4 & 4 & 1 & 2 & 1 & 0 & 1 \\
\hline Enterobacter cloacae (1) & 0 & 0 & 0 & 0 & 0 & 0 & 0 & 0 & 0 & 0 & 0 & 0 & 0 & 1 & 0 & 1 & 1 & 1 & 0 & 0 & 0 & 0 \\
\hline Escherichia coli (2) & 0 & 0 & 0 & 0 & 0 & 0 & 0 & 1 & 0 & 0 & 0 & 0 & 0 & 1 & 0 & 1 & 2 & 1 & 0 & 0 & 0 & 0 \\
\hline Erwinia herbicola (2) & 0 & 0 & 0 & 0 & 0 & 0 & 0 & 0 & 0 & 0 & 0 & 0 & 0 & 0 & 0 & 2 & 2 & 0 & 0 & 0 & 0 & 0 \\
\hline Proteus mirabilis (2) & 0 & 1 & 0 & 0 & 0 & 0 & 0 & 0 & 0 & 1 & 0 & 0 & 0 & 2 & 0 & 2 & 2 & 2 & 1 & 0 & 0 & 0 \\
\hline Serratia liquefaciens (2) & 0 & 0 & 0 & 0 & 0 & 0 & 0 & 0 & 0 & 0 & 0 & 0 & 0 & 0 & 0 & 1 & 1 & 1 & 0 & 0 & 0 & 0 \\
\hline \multirow[t]{2}{*}{ Shigella spp. (1) } & 0 & 0 & 0 & 0 & 1 & 1 & 1 & 1 & 1 & 1 & 1 & 1 & 1 & 1 & 1 & 1 & 1 & 1 & 1 & 0 & 0 & 0 \\
\hline & \multicolumn{22}{|c|}{ Number of antimicrobial resistant strains of the perianal region $C$. perspicillata } \\
\hline E. agglomerans (1) & 0 & 0 & 0 & 0 & 0 & 0 & 1 & 1 & 1 & 1 & 1 & 1 & 1 & 1 & 1 & 1 & 1 & 1 & 1 & 0 & 0 & 0 \\
\hline E. $\operatorname{coli}(1)$ & 0 & 0 & 0 & 0 & 0 & 0 & 0 & 0 & 0 & 0 & 0 & 0 & 0 & 0 & 0 & 1 & 1 & 0 & 0 & 0 & 0 & 0 \\
\hline E. herbicola (2) & 0 & 0 & 0 & 0 & 0 & 0 & 0 & 0 & 0 & 0 & 0 & 0 & 0 & 1 & 0 & 0 & 2 & 2 & 0 & 0 & 0 & 0 \\
\hline
\end{tabular}

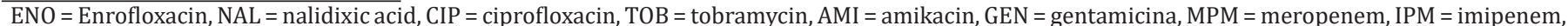

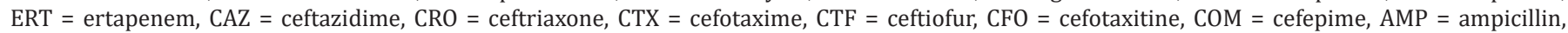
$\mathrm{AMO}=$ amoxicillin, $\mathrm{AMC}=$ amoxicillin + clavulanic acid, ATM = aztreonam, $\mathrm{SUT}=$ sulfazotrim, TET = tetracycline, $\mathrm{CLO}=$ chloramphenicol. 
abiotic and biotic factors, evidencing the conservation of the location (Figueiredo 1997, Bizerril \& Raw 1998).

This could be an explanation for the low resistance to antimicrobials for the bacteria isolated in these species of bats, however, the multiresistance presented by some bacteria to different classes of antibiotics found in some individuals of C. perspicillata individuals is of concern, since these animals are much more sociable, sharing not only their permanence location during latency and sleep, but also sharing food, which could disseminate isolates with resistant genotypes among the individuals in the communities where they live.

Bacterial resistance has been a unique health issue over many decades and it still has a long road to go. According to Boucher et al. (2009), the quick evolution and propagation of multi-resistant bacteria together with the insufficient development of new drugs may have serious effects in a not-so-distant future for the treatment of infections, mainly those caused by gram-negative bacteria, in both animals and human beings.

The economy of developing countries relies in the dependence of agriculture and cattle breeding, activities that are known for the use of antimicrobials to increase productivity, with consequent selection of resistant bacteria, which are then found in the microbiota of animals, humans and in the environment (Capita \& Alonso-Calleja 2013).

The increase in the demand of production animals and planting areas has caused the degradation of forest areas existing in private properties, reducing them, and thus reducing the habitat and survival conditions of wild animals. Therefore, they are directly or indirectly closer to the human being (Brasil 2003). The three areas in the study presented similar characteristics when evaluating the contact with humans, or with other animals, since they are fragments near planting and farming areas.

Against the results shown in the research, most developing countries have invested amounts well below the global average in expenses with public health in relation to its GDP. While the global average is $6.5 \%$ investment, according to data from the World Bank (Bonelli et al. 2014), in 2014, Brazil invested $4.7 \%$ of its GDP in health, according to data presented by the secretary of Science, Technology and Strategic Inputs from the Ministry of Health (CFF 2015).

\section{CONCLUSIONS}

Bacterial dissemination does not respect geographical barriers. The existence of multi-resistant enterobacterial isolates has been characterized among frugivorous bats in the micro region of Umuarama, in the northwestern area in the state of Paraná. Therefore, special care is necessary, since the studies performed in remaining forestry areas where it was first believed to not having its native fauna exposed to antimicrobials.

Since the flight capabilities of the bats ease the dispersion of everything they host, there is the possibility of dispersion of these enterobacteria with zoonotic potential to the local cattle breeding, as well as to other wild animals that might inhabit the area.

Nevertheless, humans can be contamined to these enterobacteria, since these species of bats are sharing food (fruit) with the communities neighboring the forest areas under study. Thus, there is the risk of such fruit being consumed without the necessary hygiene and protective, posing the health of humans in risk.

Therefore, further studies on the wild fauna are extremely important, as well as constant monitoring of these populations, mainly chiroptera, due to the risk of disseminating bacteria, which could contaminate the environment, changing common factors and unbalancing the host/parasite status.

Acknowledgements.- The authors would like to thank Universidade Paranaense (UNIPAR) for the funding granted to this research.

\section{REFERENCES}

Baker K.J., Hofer S.R., Porter C.A. \& Van D.B.R.A. 2003. Diversification among New World leaf-nosed bats: an evolutionary hypothesis and classification inferred from digenomic congruence of DNA sequence. Spec. Publ. Mus. Texas Tech Univ. 203:1-36.

Barquez R.M. \& Díaz M.M. 2009. Los Murciélagos de Argentina: clave de identificación. El autor, Tucumán. 84p.

Bianconi G.V., Mikich S.B. \& Pedro W.A. 2004. Diversidade de morcegos (Mammalia, Chiroptera) em remanescentes florestais do município de Fênix, noroeste do Paraná, Brasil. Revta Bras. Zool. 21(4):943-954. http:// dx.doi.org/10.1590/S0101-81752004000400032.

Bizerril M.X.A. \& Raw A. 1998. Feeding behaviour of bats and the dispersal of piper arboreum seeds in Brazil. J. Trop. Ecol. 14(01):109-114. http:// dx.doi.org/10.1017/S0266467498000108.

Bonelli R.R., Moreira B.M. \& Picão R.C. 2014. Antimicrobial resistance among Enterobacteriaceae in South America: History, current dissemination status and associated socioeconomic factors. Drug Resist. Updates 17(1-2):24-36. http://dx.doi.org/10.1016/j.drup.2014.02.001. PMid:24618111.

Boucher H.W., Talbot G.H., Bradley J.S., Edwards J.E., Gilbert D., Rice L.B., Scheld M., Spellberg B. \& Bartlett J. 2009. Bad bugs, no drugs: no ESKAPE! An update from the infectious Diseases Society of America. Clin. Infect. Dis. 48(1):1-12. http://dx.doi.org/10.1086/595011. PMid:19035777.

Brasil 2003. Fragmentação de Ecossistemas: causas, efeitos sobre a biodiversidade e recomendações de políticas públicas. Ministério do Meio Ambiente (MMA), Brasília. 510p.

Capita R. \& Alonso-Calleja C. 2013. Antibiotic-resistant bacteria: a challenge for the food industry. Crit. Rev. Food Sci. 53(1):11-48. http://dx.doi.org/ 10.1080/10408398.2010.519837. PMid:23035919.

Carvalho M. 2007. Colibacilose e salmanelose, p.742-750. In: Cubas Z.S., Silva J.C.R. \& Catão-Dias J.L. (Eds), Tratado de Animais Selvagens: medicina veterinária. Roca, São Paulo.

CFF 2015. Brasil é um dos Países que Menos Investem em Saúde Pública. Conselho Federal de Farmácia. Available at <https://goo.gl/GqoNp9> Access on Feb. 20, 2016.

CLSI 2013. Suggested Grouping of US-FDA Approved Antimicrobial Agents that Should be Considered for Routine Testing and Reporting on Nonfastidious Organisms by Clinical Laboratories. Publication M100-S23.

Corrêa I.M.O., Flores F., Schneiders G.H., Pereira L.Q., Brito B.G. \& Lovato M. 2013. Detecção de fatores de virulência de Escherichia coli e análise de Salmonella spp. em psitacídeos. Pesq. Vet. Bras. 33(2):241-246. http:// dx.doi.org/10.1590/S0100-736X2013000200017.

Costa L.M., Prata A.F.D., Moraes D., Conde F.V., Jordão-Nogueira T. \& Esbérard C.E.L. 2006. Deslocamento de Artibeus fimbriatus sobre o mar. Chiropt. Neotrop. 12:289-290.

Esbérard C.E.L., Freitas G.P., Luz J.L., Costa L.M. \& Freitas L.N. 2011. Intervalos máximos entre capturas e recapturas de morcegos no Estado do Rio de janeiro, Sudeste do Brasil. Chiropt. Neotrop. 17:957-962. 
Figueiredo R.A. 1997. Fenologia e ecologia da polinização de espécies Piperaceae em mata semidecídua do sudeste brasileiro. Tese de Doutorado, Universidade Estadual de Campinas, Campinas. Available at <https://goo. gl/2v9RLt> Access on Dec. 23, 2015.

Friggens M.M. \& Beier R. 2010. Anthropogenic disturbance and the risk of flea-borne disease transmission. Oecology 164(3):809-820. http://dx.doi. org/10.1007/s00442-010-1747-5. PMid:20740292.

Gerlach H. 1994. Bacteria, p.949-983. In: Ritchie B.W., Harrison G.J. \& Harrison L.R. (Eds), Avian Medicine: principles and application, Wingers Publishing, Lake Worth.

Greenhall A.M., Joermann G. \& Schimdt U. 1983. Desmodus rotundus. Mammalian Species, Washington 202:1-6.

Gregorin R. \& Taddei V.A. 2002. Chave artificial para a identificação de molossídeos brasileiros (Mammalia, Chiroptera). Mastozool. Neotrop. 9:13-32.

Hortêncio-Filho H., Lima P. \& Fogaça F.N.O. 2007. Subfamília Carolliinae, p.99105. In: Reis N.R., Peracchi A.L., Pedro W.A. \& Lima I.P. (Eds), Mamíferos do Brasil. Divisão de Processos Técnicos da Biblioteca Central da Universidade Estadual de Londrina, Londrina.

Hortêncio-Filho H., Reis N.R., Pinto D., Anderson R., Testa D.A. \& Marques M.A. 2005. Levantamento dos morcegos (Chiroptera, Mammalia) do Parque Municipal do Cinturão Verde de Cianorte, Paraná, Brasil. Chiropt. Neotrop. 14:211-215.

Iapar 2015. Cartas Climáticas do Paraná. Instituto Agronômico do Paraná, Curitiba. Available at <https://goo.gl/ocyHUX> Access on July 18, 2015.

Ipardes 2012. Relação dos Municípios do Estado Ordenados Segundo as Mesorregiões e as Microrregiões Geográficas do IBGE, Paraná. Instituto Paranaense de Desenvolvimento Econômico e Social. Available at <https:// goo.gl/vsrZYu> Access on Dec. 7, 2015.

Jones K.E., Bininda-Emonds O.R.P. \& Gittleman J.L. 2005. Bats, clocks, and rocks: diversification patterns in Chiroptera. Evolution 59(10):2243-2255. http://dx.doi.org/10.1111/j.0014-3820.2005.tb00932.x. PMid:16405167.

Koopman K.F. 1993. Order Chiroptera, p.137-241. In: Wilson D.E. \& Reeder D. (Eds), Mammals Species of the World: a taxonomic and geographic reference. 2nd ed. Smithsonian Institution Press, Washington, DC.

Lim B.K., Engstrom M.D., Lee-Junior T.E., Patton J.C. \& Bickham J.W. 2004. Molecular differentiation of large species of fruit-eating bats (Artibeus) and phylogenetic relationships based on the cytochrome $b$ gene. Acta Chirop. 6(1):1-12. http://dx.doi.org/10.3161/001.006.0101.

Martins L.R.L., Simões R.L.R., Matos A.J.F., Costa P.M.R. \& Salazar A. 2013. Common phenotypic and genotypic antimicrobial resistance patterns found in a case study of multiresistant $E$. coli from cohabitant pets, humans, and household surfaces. J. Environ. Health 75(6):74-81. PMid:23397653.

Mateu E. \& Martin M. 2001. Why is anti-microbial resistance a veterinary problem as well? J. Vet. Med. B 48(8):569-581. http://dx.doi.org/10.1046/ j.1439-0450.2001.00475.x. PMid:11708676.

Mattes B.R., Consiglio S.A.S., Almeida B.Z., Guido M.C., Orsi R.B., Silva R.M., Costa A., Ferreira A.J.P. \& Knobl T. 2005. Influência da biossegurança na colonização intestinal por Escherichia coli em psitacídeos. Arqs Inst. Biológico, São Paulo 72:13-16.

Mion L., Colla F.L., Cisco I.C., Webber B., Diedrich L.N., Pilotto F., Rodrigues L.B., Nascimento V.P. \& Santos L.R. 2014. Perfil de resistência a antimicrobianos por Salmonella Heidelberg isoladas de abatedouro avícola em 2005 e 2009. Acta Scient. Vet. 42:1197.

Miretzki M. 2003. Morcegos do Estado do Paraná, Brasil (Mammallia, Chiroptera): riqueza de espécies, distribuição e síntese do conhecimento atual. Pap. Avulsos Zool. 43(6):101-138. http://dx.doi.org/10.1590/ S0031-10492003000600001.

Nascimento A.M.A., Cursino L., Gonçalves-Dornelas H., Reis A., Chartone-Souza E. \& Marini M.A. 2003. Antibiotic-resistant gram-negative bacteria in birds from the Brazilian Atlantic Forest. Condor 105(2):358-361. http://dx.doi org/10.1650/0010-5422(2003)105[0358:AGBIBF]2.0.CO;2.

Normanno G., Corrente M., La Salandra G., Dambrosio A., Quaglia N.C., Parisi A., Greco G., Bellacicco A.L., Virgilio S. \& Celano G.V. 2007. Methicillinresistant Staphylococcus aureus (MRSA) in foods of animal origin product in Italy. Int. J. Food Microbiol. 117(2):219-222. http://dx.doi.org/10.1016/j. ijfoodmicro.2007.04.006. PMid:17533002.

Omatsu T., Watanabe S., Akashi H. \& Yoshikawa Y. 2007. Biological characters of bats in relation to natural reservoir of emerging viruses. Comp. Immunol. Microbiol. Infect. Dis. 30(5/6):357-374. http://dx.doi.org/10.1016/j cimid.2007.05.006. PMid:17706776.

Passos F.C., Silva W.R., Pedro W.A. \& Bonin M.R. 2003. Frugivoria em morcegos (Mammalia, Chiroptera) no Parque Estadual Intervales Sudeste do Brasil. Revta Bras. Zool. 20(3):511-517. http://dx.doi.org/10.1590/S010181752003000300024 .

Paterson D.L. 2006. Resistance in gram-negative bacteria: enterobacteriaceae. Am. J. Med. 119(6, Suppl. 1):62-70. http://dx.doi.org/10.1016/j. amjmed.2006.03.013. PMid:16735147.

Peracchi A.L., Lima I.P.R., Reis N.R., Nogueira M.R. \& Ortêncio-Filho H. 2006. Ordem Chiroptera, p.153-230. In: Reis N.R., Peracchi A.L., Pedro W.A. \& Lima I.P. (Eds), Mamíferos do Brasil. Divisão de Processos Técnicos da Biblioteca Central da Universidade Estadual de Londrina, Londrina.

Perkins S.E., Cattadori I. \& Hudson P.J. 2005. The role of mammals in emerging zoonoses. Mammal Study 30(Suppl.1):67-71. http://dx.doi. org/10.3106/1348-6160(2005)30[S67:TROMIE]2.0.CO;2.

Quinn P.J., Markey B.K., Carter M.E. \& Leonard F.C. 2007. Microbiologia Veterinária e Doenças Infecciosas. Artmed, Porto Alegre. 512p.

Reis N.R., Fregonezi M.N., Peracchi A.L. \& Shibatta O.A. 2013. Morcegos do Brasil: guia de campo. Technical Books, Rio de Janeiro. 252p.

Reis N.R., Peracchi A.L., Lima I.P. \& Pedro W.A. 2006. Riqueza de espécies de morcegos (Mammalia, Chiroptera) em dois diferentes habitats, na região centro-sul do Paraná, sul do Brasil. Revta Bras. Zool. 23(3):813-816. http:// dx.doi.org/10.1590/S0101-81752006000300028.

Santos H.F., Flôres M.L., Lara V.M., Silva M.S., Battisti L. \& Lovato L.T. 2010 Microbiota cloacal aeróbia de cracídeos cativos no Rio Grande do Sul e sua susceptibilidade a antimicrobianos. Pesq. Vet. Bras. 30(12):1077-1082 http://dx.doi.org/10.1590/S0100-736X2010001200013.

Simmons N.B. 2005. Order Chiroptera, p.312-529. In: Wilson D.E. \& Reeder D.M. (Eds), Mammal Species of the World: a taxonomic and geographic reference. Vol.1. 3rd ed. Jonhs Hopkins University Press, Baltimore.

Steele C.M., Brown R.N. \& Botzler R.G. 2005. Prevalence of zoonotic bacteria among seabirds in rehabilitation centers along the Pacific Coast of California and Washington, USA. J.Wildl. Dis. 41(4):735-744. http://dx.doi. org/10.7589/0090-3558-41.4.735. PMid:16456162.

Straube F.C. \& Bianconi G.V. 2014. Sobre a grandeza e a unidade utilizada para estimar esforço de captura com utilização de redes-de-neblina. Chiropt. Neotrop. 8:150-152.

Tompkins D.M., Dunn A.M., Smith M.J. \& Telfer S. 2011. Wildlife diseases: from individuals to ecosystems. J. Anim. Ecol. 80(1):19-38. http://dx.doi org/10.1111/j.1365-2656.2010.01742.x. PMid:20735792.

Trabulsi L.R. \& Alterthum F. 2004. Microbiologia. 4⿳⺈ ed. Atheneu, São Paulo. $718 \mathrm{p}$.

Ungemach F.R., Muller-Bahrdt D. \& Abraham G. 2006. Guidelines for prudent use of antimicrobials and their implications on antibiotic usage in veterinary medicine. Int. J. Med. Microbiol. 296(Suppl. 41):33-38. http://dx.doi. org/10.1016/j.ijmm.2006.01.059. PMid:16520092.

van den Bogaard A.E. \& Stobberingh E.E. 2000. Epidemiology of resistance to antibiotics: link between animals and humans. Int. J. Antimicrob. Agents 14(4):327-335. http://dx.doi.org/10.1016/S0924-8579(00)00145-X. PMid:10794955. 
Vizotto L.D. \& Taddei V.A. 1973. Chave para determinação de quirópteros brasileiros. Bolm Ciências, Revta Fac. Fil. Ciênc. Letras, 1:1-72.

von Wintersdorff C.J.H., Penders J., Stobberingh E.E., Lashof A.M.L.O., Hoebe C.J.P.A., Savelkoul P.H.M. \& Wolffs P.F.G. 2014. High rates of antimicrobial drug resistance gene acquisition after international travel, the Netherlands. Emerg. Infect. Dis. 20(4):649-657. http://dx.doi.org/10.3201/eid2004.131718. PMid:24655888.
Wells J., Kim M., Bono J.L., Kuehn L.A. \& Benson A.K. 2014. Meat science and muscle biology symposium: Escherichia coli 0157:H7, diet, and fecal microbiome in beef cattle. J. Anim. Sci. 92(4):1345-1355. http://dx.doi. org/10.2527/jas.2013-7282. PMid:24492542.

Zórtea M. 2007. Sub-familia Stenodermatinae, p.107-128. In: Reis N.R., Peracchi A.L., Pedro W.A. \& Lima I.P. (Eds), Morcegos do Brasil. Nélio R. dos Reis, Londrina. 